\title{
DISTRIBUTION OF FOREIGN EMPLOYEES IN SLOVAKIA
}

\author{
Komornik Jozef ${ }^{1}$ \\ Smolen Jan ${ }^{2}$ \\ Dudić Branislav ${ }^{3}$ \\ Beresova Gabriela ${ }^{4}$
}

\begin{abstract}
This work analyses the structure of foreign workforce in Slovakia by job category and country of origin. The foreign employees were divided into 9 job categories by level of sophistication ranging from leading workforce in organizations to auxiliary and unskilled workers. It has been found that the majority of employees in more sophisticated job categories are coming to Slovakia from larger and more developed economies, while those less sophisticated positions in Slovakia are mostly filled with Romanian, Hungarian and Ukrainian nationals. A very important role in almost all categories, irrespective of proficiency level, is played by nationals from The Czech Republic. This shows that close economic ties between The Czech Republic and Slovakia are reflected also on the labor market. The findings of this
\end{abstract}

1 Comenius University Faculty of Management, Bratislava, Odbojárov 10, 82005 Bratislava, Slovak Republic, e-mail: jozef.komornik@fm.uniba.sk

2 Comenius University Faculty of Management, Bratislava, Odbojárov 10, 82005 Bratislava, Slovak Republic, e-mail: jan.smolen@fm.uniba.sk

3 University Business Academy, Faculty of Economics and Engineering Management, Cvećarska 2, 21000 Novi Sad, Republic of Serbia, e-mail: branislav.dudic@fimek.edu.rs; and Comenius University, Faculty of Management, Odbojárov 10, 82005 Bratislava, Slovakia.

4 Comenius University Faculty of Management, Bratislava, Odbojárov 10, 82005 Bratislava, Slovak Republic, e-mail: gabriela.beresova@fm.uniba.sk 
study have important implications for the labor market in Slovakia, as it has been shown in many research studies so far, that immigrant labor composition impacts various labor market variables.

Keywords: workers' migration / employment in Slovakia / workforce distribution

\section{INTRODUCTION}

The relevance of foreign workers for Slovak economy has increased substantially during the last 5 years. This was presumably triggered by the economic growth of Slovakia, which has been higher than the EU average in the recent years, and by changes in regulations, as it is becoming gradually easier to employ foreigners in Slovakia. Out of 52 000 jobs created in 2018, foreign employees have filled 8500 (more than $16 \%$ ), while the total number of foreign workers in Slovakia has reached 50000 in year 2018. A similar situation happened in the year 2019. The outlook for 2020 has been significantly affected by the COVID 19 epidemics so the change in the trend shown in the previous years can be seen.

As relevance of foreign workforce for Slovak economy increases, discussions regarding the proper rules for employing foreign workers in Slovakia are also becoming more common. There are views that foreign employees decrease the average wage paid in Slovakia and while this factor benefits the employers, the effect could be exactly the opposite on domestic employees. Furthermore, cultural differences between employers and employees from different countries also lead to certain problems and workplace issues. The composition of population in different municipalities has also changed.

For the purpose of this study, we divided foreign employees in Slovakia into 9 categories by level of job sophistication and country of origin. This is the division used by the official statistics of the Slovak Agency for Employment, Social Issues and Family (Ústredie práce, sociálnych vecí a rodiny). The composition of foreign workforce was then analyzed from these two perspectives to determine if there is any relationship between the two factors analyzed. 


\section{LITERATURE REVIEW}

The analysis in this paper concentrates on the composition of the foreign workforce in Slovakia. The presented findings have important implications for the Slovak job market as large number of published research articles have stated significant correlations between migrant workers statistics and other labor market characteristics.

The new generation of workforce was raised in a globalized world and the labor market needs to adjust as this generation gradually replaces the older workers (Mitkova, 2016). This new generation is significantly more flexible and prone to relocation when searching for most suitable employment and living conditions. This certainly creates more opportunities and challenges for the firms. It has been confirmed (Kajanova 2011) that the creation of competitive advantage in globalized labor markets is based on a different set of skills, including flexibility, adaptability and mobility. While global corporations are usually aware of these trends and adjust accordingly, challenges might be more significant for small and medium enterprises, which sometimes lack human and financial capital needed to pay sufficient attention to the latest trends. Small and medium enterprises employ a majority of employees in Slovakia at 56\% (Rentkova, 2019) which is a substantial increase from 2014 when this number constituted 41\% (Mrva, 2014). This number is also one of the highest in EU, underlying the crucial role of small and medium enterprises for the Slovak labor market.

Considering the impacts of migration on the labor market, empirical findings suggest that migration has a small but positive and statistically significant impact on the growth of low-wage occupations in the EU 15 as a whole (Andersson, 2015). However, this impact has been visible particularly in the southern countries, such as UK and Ireland, while that impact in the northern economies has been negligible. It was also found that it is harder for immigrants from poorer countries to climb the income ladder and such employees are more segregated as compared to the employees from the richer countries. An important and controversial topic is the impact of immigrant workers on the wages in a country where they work. Research studies analyzing this issue have not come to clear conclusions in this respect. Some researchers have found a clear relationship (Card, 2001), (Borjas, 2003), while others have found only very limited impact (Eva, 2016), (Dustmann, 2005). Dustmann (2015) further states that wage adjustment is only one of the factors which companies use 
to deal with the changes in labor supply, while scale adjustment between production units and factor intensity between production units are the other ones.

\section{JOB CATEGORIES ANALYZED}

Nine job categories (A-I) have been analyzed in this paper and summarized in Table 1. These groups are based on the division used by the Slovak Agency for Employment, Social Issues and Family (Ústredie práce, sociálnych vecí a rodiny) and the analyzed data are from January 2018. Table 1. also shows the number of employees in every group and the number of employees from the country with most workers in each group (so $24.1 \%$ of all foreign leading employees employed in Slovakia came from The Czech Republic). The last three columns show the number of countries in top 3 quartiles, 9 deciles and 99 centiles of employee distribution in each group (so $75 \%$ of foreign leading employees in Slovakia come from 9 countries with highest percentages).

Table 1. Categories of foreign employees in Slovakia and the number of countries in top 3 quartiles, 9deciles and 99 centiles of distribution.

\begin{tabular}{|c|c|c|c|c|c|}
\hline Category & Name of Category & First place & $\begin{array}{c}\text { top } \\
\mathbf{7 5 \%}\end{array}$ & $\begin{array}{c}\text { top } \\
\mathbf{9 0 \%}\end{array}$ & $\begin{array}{c}\text { top } \\
\mathbf{9 9 \%}\end{array}$ \\
\hline A & Leading employees & $\begin{array}{c}\text { Czech Republic: } \\
487 / 2020(24.1 \%)\end{array}$ & 9 & 16 & 32 \\
\hline B & Specialists & $\begin{array}{c}\text { Czech Republic: } \\
778 / 3636(24.4 \%)\end{array}$ & 10 & 18 & 37 \\
\hline C & $\begin{array}{c}\text { Technical and expert } \\
\text { workers }\end{array}$ & $\begin{array}{c}\text { Romania: } 478 / 2603 \\
(18.4 \%)\end{array}$ & 8 & 15 & 31 \\
\hline D & Administrative staff & Poland: 197/1273 (15.5\%) & 7 & 15 & 35 \\
\hline E & $\begin{array}{c}\text { Employees in service and } \\
\text { trade }\end{array}$ & $\begin{array}{c}\text { Czech Republic: } \\
\text { 539/2056 (26.2\%) }\end{array}$ & 7 & 11 & 25 \\
\hline F & $\begin{array}{c}\text { Qualified workers in } \\
\text { agriculture and forestry }\end{array}$ & $\begin{array}{c}\text { Romania: } \\
95 / 186(51.1 \%)\end{array}$ & 3 & 5 & 10 \\
\hline G & $\begin{array}{c}\text { Qualified workers and } \\
\text { craftsmen }\end{array}$ & $\begin{array}{c}\text { Romania: } \\
901 / 3784(23.8 \%)\end{array}$ & 5 & 7 & 18 \\
\hline H & $\begin{array}{c}\text { Machine and equipment } \\
\text { operators and assemblers }\end{array}$ & $\begin{array}{c}\text { Romania: } \\
4230 / 13793(30.7 \%)\end{array}$ & 4 & 7 & 19 \\
\hline I & $\begin{array}{c}\text { Auxilary and unskilled } \\
\text { workers }\end{array}$ & $\begin{array}{c}\text { Romania: } 1748 / 3686 \\
(47.4 \%)\end{array}$ & 3 & 6 & 12 \\
\hline
\end{tabular}

Data source: Slovak Agency for Employment, Social Issues and Family 
Based on this table it is obvious that country diversification of employees in higher levels of specialization is much higher than in the lower levels. Three quartiles of employee distribution come from only 3-5 countries in lower levels of specialization and from 8-10 countries in higher levels of specialization. The same analysis for 99 centiles in more sophisticated groups shows that employees from more than 30 countries are represented, while in the less specialized employee group the number of countries reaches only 10 to 20 countries.

\section{RESULTS}

The main output of this paper is summarized in Table 2. In this table, countries represented in the $9^{\text {th }}$ decile of foreign employee distribution in a particular specialization category are shown. Different colors in the table mark different group of countries. Countries which were in the EU in 2003 are marked with blue. Green represents other developed world economies, members of G-20 Visegrad countries (Hungary, Poland), while economies with close ties to Slovakia are marked with red. Darker red is then assigned to The Czech Republic, which, even among the Visegrad economies has the closest ties with Slovakia.

It has been clearly shown that highly specialized workers come to Slovakia predominantly from the EU-2003 and G-20 countries (marked with green and blue in Table 1.), while the less specialized workers come from countries which have joined the EU after the year 2003, Ukraine, Serbia and Vietnam.

The impact of the country of origin on the level of specialization of employees coming to Slovakia is substantial. In the top two groups by specialization, 22 of the 34 countries (65\%) in the 9th decile of distribution, were represented by the G-20 or the EU-2003 countries. This percentage has decreased to $44 \%$ for the next 3 groups, while there were no countries from the G-20 or EU-2003 represented in the ninth decile of distribution in the last 4 groups by specialization. 
Table 2. Distribution of foreign employees in Slovakia by job category and country of origin.

\begin{tabular}{|c|l|l|}
\hline Category & \multicolumn{1}{|c|}{ Name of Category } & \multicolumn{1}{|c|}{$\begin{array}{c}\text { Countries in top 90\% } \\
\text { (blue: EU-2003, green: G20, red: CZ,PL,HU) }\end{array}$} \\
\hline A & Leading employees & $\begin{array}{l}\text { CZ, KR, DE, IT, FR, AT, GB, HU, PL, UA, RO, RU, BE, ES, } \\
\text { DK, NE }\end{array}$ \\
\hline B & Specialists & $\begin{array}{l}\text { CZ, UA, PL, IT, DE, HU, RO, GB, ES, FR, RU, US, KR, AT, } \\
\text { IN, BG, GR, RS }\end{array}$ \\
\hline C & $\begin{array}{l}\text { Technical and expert } \\
\text { workers }\end{array}$ & $\begin{array}{l}\text { RO, CZ, HU, PL, IT, UA, BG, ES, FR, DE, KR, GR, AT, PT, } \\
\text { GB }\end{array}$ \\
\hline D & Administrative staff & PL, CZ, RO, HU, IT, ES, FR, VN, BG, DE, UA, PT, AT, RS, TR \\
\hline E & $\begin{array}{l}\text { Employees } \\
\text { in service and trade }\end{array}$ & CZ, HU, PL, RO, HR, CN, VN, BG, UA, RS, DE \\
\hline F & $\begin{array}{l}\text { Qualified workers in } \\
\text { agriculture and forestry }\end{array}$ & RO, UA, CZ, HU, BG \\
\hline G & $\begin{array}{l}\text { Qualified workers and } \\
\text { craftsmen }\end{array}$ & RO, CZ, HU, UA, PL, BG, RS \\
\hline H & $\begin{array}{l}\text { Machine and Equipment } \\
\text { Operators and Assemlers }\end{array}$ & RO, RS, HU, UA, CZ, BG, VN \\
\hline I & $\begin{array}{l}\text { Auxiliary and unskilled } \\
\text { workers }\end{array}$ & RO, HU, CZ, PL, RS, BG \\
\hline
\end{tabular}

Data source: Slovak Agency for Employment, Social Issues and Family

Of the EU-2003 countries, most employees are coming to work in Slovakia from Italy and Germany. Other G-20 economies are represented particularly by Russia and South Korea. However, the majority of foreign employees are coming to work in Slovakia from other countries, particularly the Visegrad Group members, Romania and Ukraine. It is interesting to note here that while Visegrad member countries, particularly the Czech Republic, lead the more specialized categories, Romania dominates the lower levels of specialization distribution.

\section{CONCLUSIONS}

The analysis presented in this paper confirms that there is high correlation between country of origin of foreign employees and their level of specialization. This is in line with the findings presented by other researchers, who state that it is harder for migrant workers from poorer countries to climb the income ladder. Their level of segregation is also higher. It has also been found that most employees come to Slovakia from poorer countries to perform less specialized professions. This might create a problem for the Slovak labor market, which needs to be addressed as creation of poor segregated communities is something that 
should be avoided. Experience with negative trends which often occur in such communities are well known in Slovakia.

While the impact of foreign employees on average wages is inconclusive as researchers have come to different conclusions by analyzing different time periods and regions, it has been generally found that less skilled workers are also easier exploited. As the majority of foreign workers who come to Slovakia are from poorer countries, this impact of foreign workers on wages can be higher than average.

As Slovak government has created very encouraging conditions for the process of hiring foreign workers with lower specialization, it might need to reconsider this strategy. Generally, it has been confirmed that the level of specialization of labor markets particularly in the globalized world is of crucial importance for the creation of a long standing competitive advantage of a particular economy.

\section{REFERENCES}

1. Andersson, L.F., Eriksson, R. \& Scocco, S. (2019). Refugee immigration and the growth of low-wage work in the EU15.CMS 7, 39

2. Borjas, G. J. (2003). The labor demand curve is downward sloping: Reexamining the impact of immigration on the labor market. Quarterly Journal of Economics, 118(4), 1335-1374.

3. Dustmann, C., Hatton, T., \& Preston, I. $(2005)$. The labour market effects of immigration. The Economic Journal, 115, 297-299.

4. Dustmann C., \& Glitz A. (2015). How Do Industries and Firms Respond to Changes in Local Labor Supply? Journal of Labor Economics 33(3), pp. 711-750

5. Card, D. (2001). Immigrant inflows, native outflows and the local labor market impacts of higher immigration. Journal of Labor Economics, 19, 22-64.

6. Mitkova, L. \& Mariak, V. (2015). The First Globalized Generation Generation Y. 15th Globalization and its socio-economic consequences conference. Rajecke Teplice.

7. Rentkova, K. (2019). The Clusters Phenomenon and Sustainable Regional Development. IOP Conference Series: Materials Science and Engineering. 471.

8. Mrva, M. \& Stachova, P. (2014). Regional Development and Support of SMEs - How University Project can Help. Procedia - Social and Behavioral Sciences. 110. 617-626.

9. Kajanova, J. (2011). The Competitive Advantage in the Global Labour Market. Business, Management and Education. 9. 
10. Rodriguez-Planas N. (2012) Wage and occupational assimilation by skill level: migration policy lessons from Spain. IZA Journal of European Labor Studies 1(1), p. 8.

11. Eva, M.-G., \& Tritah, A. (2016). The effects of immigration in frictional labor markets: Theory and empirical evidence from EU countries. European Economic Review, 84, 76-98.

\title{
DISTRIBUCIJA STRANACA ZAPOSLENIH U SLOVAČKOJ
}

\author{
Komornik Jozef \\ Smolen Jan \\ Dudić Branislav \\ Beresova Gabriela
}

Sažetak: Ovaj rad analizira strukturu strane radne snage u Slovačkoj prema kategoriji posla i zemlji porekla. Strani zaposleni bili su podeljeni u devet kategorija posla, prema stepenu sofisticiranosti, od vodećih radnika do pomoćnih i nekvalifikovanih radnika. Pokazano je da većina zaposlenih $u$ sofisticiranijim kategorijama poslova dolazi $u$ Slovačku iz većih i razvijenijih ekonomija, dok su manje sofisticirane pozicije u Slovačkoj uglavnom popunjene državljanima Rumunije, Mađarske i Ukrajine. Veoma važnu ulogu u skoro svim kategorijama, nezavisnim od nivoa stručnosti, imaju državljani Češke. To pokazuje da se bliske ekonomske veze između Češke i Slovačke odražavaju $i$ na tržištu rada. Nalazi ovog rada imaju značajne implikacije na tržište rada u Slovačkoj, jer je pokazano u mnogim istraživačkim studijama da sastav imigrantske radne snage utiče na razne varijable na tržištu rada.

Ključne reči: migracije radnika / zaposlenost u Slovačkoj / raspodela radne snage 